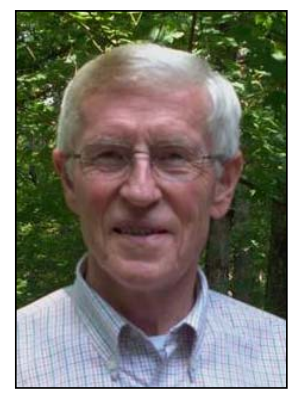

\author{
THE ECONOMIC PAMPHLETEER \\ JOHN IKERD
}

\title{
Toward an Ethic of Sustainability
}

Published online May 14, 2016

Citation: Ikerd, J. (2016). Toward an Ethic of Sustainability. Journal of Agriculture, Food Systems, and Community Development, 6(3), 3-5. http://dx.doi.org/10.5304/jafscd.2016.063.001

Copyright (C) 2016 by New Leaf Associates, Inc.

Sustainable farming is ultimately an ethical $S_{\text {commitment. As I have written in a previous }}$ column, "There are lots of other occupations where people can make more money with far fewer physical and intellectual challenges.... Unless they truly believe that farming is their 'calling,' I advise would-be farmers to choose other occupations" (Ikerd, 2015a, p. 10). A purpose or calling determines what a person should and should not do with their lives and thus is a matter of ethics.

In a previous column, I proposed a Food Ethic

John Ikerd is professor emeritus of agricultural economics, University of Missouri, Columbia. He was raised on a small farm and received his $B S, M S$, and $P h D$ degrees from the University of Missouri. He worked in the private industry prior to his 30-year academic career at North Carolina State University, Oklahoma State University, the University of Georgia, and the University of Missouri. Since retiring in 2000, he spends most of his time writing and speaking on issues of sustainability. Ikerd is author of six books and numerous professional papers, which are accessible at http://johnikerd.com and http://web.missouri.edu/ ikerdj as a guide for purposeful eating (Ikerd, 2015b). I think we also need an Ethic of Sustainability as a guide for purposeful living, in farming or any other way of life. I propose: A thing is right when it tends to enhance the quality and integrity of both buman and nonbuman life on earth by honoring the unique responsibilities and rewards of humans as members and caretakers of the earth's integral community. A thing is wrong when it tends otherwise.

First, the ethic goes beyond defining sustainable practices or even principles by defining some things we might do as "right" and others as

Why an Economic Pamphleteer? Pamphlets historically were short, thoughtfully written opinion pieces and were at the center of every revolution in western history. I spent the first half of my academic career as a freemarket, bottom-line agricultural economist. During the farm financial crisis of the 1980s, I became convinced that the economics I had been taught and was teaching wasn't working and wasn't going to work in the futurenot for farmers, rural communities, consumers, or society in general. Hopefully my "pamphlets" will help spark the needed revolution in economic thinking. 
"wrong." Questions of right and wrong cannot be answered using currently accepted scientific methods. These are matters of belief or faith. Thus scientists tend to ignore them, and consequently so do most advocates of sustainability. This has allowed the concept of sustainability to be trivialized and coopted by corporations and marginalized by government agencies.

As Pope Francis observes in his encyclical letter, Laudato Si', for Care of our Common Home, "we can note the rise of a false or superficial ecology which bolsters complacency and a cheerful recklessness. Such evasiveness serves as a license to carrying on with our present lifestyles and models of production and consumption" (Francis I, 2015, para. 59). In my opinion, "superficial sustainability" today is "bolstering complacency and cheerful recklessness" in American agriculture and is being used as a "license" for continuing unsustainable farming.

Second, the Ethic of Sustainability reflects an "integral worldview." All life on earth, including human life, is integrally interconnected and interdependent, and all living things are integrally connected with all nonliving things on earth (for a deeper discussion of worldview and sustainability, see Ikerd, Gamble, and Cox, 2015). A person's worldview, integral or otherwise, depends on his or her perception of "how the world works" and of our individual and collective roles as humans within it. Since our worldviews determine what we accept as fact or truth, an "integral worldview" is a spiritual, metaphysical, or philosophical perception of reality.

An integral worldview is not new to sustainable farming. Rudolf Steiner, the father of biodynamic farming, said, "Central to bio-dynamics is the concept that a farm is healthy only as much as it becomes an organism in itself-an individualized, diverse ecosystem guided by the farmer, standing in living interaction with the larger ecological, social, economic, and spiritual realities of which it is part" (Steiner, 1924/1993).

Third, the Ethic of Sustainability focuses on the quality and integrity of "life," meaning the whole of life on earth. Living things are the only means we have of acquiring the energy necessary to sustaining human life on earth. Our food, our clothes, our houses, and our cars all require energy to make and energy to use. Everything of any use to us, including everything of economic value, ultimately comes from the physical elements of the earth: air, water, soil, minerals. However, it's the earth's energy that makes the other elements of nature useful to humans. Sustainability ultimately depends on sustaining the usefulness of energy.

The first law of thermodynamics states that energy can neither be created nor destroyed. However, the second law, the law of entropy, states that whenever energy is used, or reused, to do anything useful, some of its usefulness is lost. Only living things, primarily plants on land and plankton in oceans, are capable of capturing, organizing, concentrating, and storing new solar energy to offset the inevitable tendency of energy toward uselessness. We humans can sequester useful energy, using windmills, falling water, and photovoltaic cells. However, we are inherently reliant on the biological energy collectors for our life's energy. So, the sustainability of human life on earth is inherently dependent on the quality, integrity, and thus the usefulness of the living world to offset the inevitable tendency of the nonliving world toward entropy or uselessness.

The emphasis of the ethic on life is also important because we can't see the loss of usefulness of energy due to entropy. Farmers can't see the loss of useful energy on their farms, but they can see the diminished quality of biological life in their soils, their crops and livestock, and the lives of the people who farm and live in their rural communities. Any approach to farming that fails to 
enhance the quality and integrity not only of human life but of all life on earth is not only unsustainable, it is morally and ethically wrong.

Finally, the Ethic of Sustainability acknowledges that our lives have purpose. Without purpose, there can be no responsibility. Concerns for sustainability arise from our uniquely human responsibilities as members and caretakers of the earth's communities. Nowhere is this responsibility clearer than in farming. As Pope Francis states, "The biblical texts are to be read in their context... recognizing that they tell us to 'till and keep' the garden of the world (cf. Gen 2:15). 'Tilling' refers to cultivating, ploughing or working, while 'keeping' means caring, protecting, overseeing and preserving...Each community can take from the bounty of the earth whatever it needs for subsistence, but it also has the duty to protect the earth and to ensure its fruitfulness for coming generations" (Francis I, 2015, para. 67).

This responsibility was clearly understood by the pioneers of sustainable agriculture. J. I. Rodale wrote, "The organiculturist farmer must realize that in him is placed a sacred trust, the task of producing food that will impart health to the people who consume it. As a patriotic duty he assumes an obligation to preserve the fertility of the soil, a precious heritage that he must pass on, undefiled and even enriched, to subsequent generations" (Rodale, 1948, Chapter 8, para. 15). Sir Albert Howard began his classic book, An Agricultural Testament, with the assertion, "The maintenance of the fertility of the soil is the first condition of any permanent system of agriculture" (Howard, 1940, Introduction, para. 1) — which is also the foundation for any permanent society.

So sustainable farming is not just an occupation; it is a calling to a life of purpose. Those who are called have an awesome responsibility, but also an opportunity for service to humanity with equally awesome rewards. Purpose gives meaning and quality to life and is the key to true human wellbeing and happiness. Most of us are called to be something other than farmers, but we should all be grateful and supportive of those who respond to an ethical calling to be farmers.

\section{References}

Francis I. (2015, May 24). Laudato Si' of the Holy Father Francis on care for our common home [Encyclical letter]. Retrieved from The Holy See website: http://w2.vatican.va/content/francesco/en/ encyclicals/documents/papa-francesco 20150524_enciclica-laudato-si.html

Howard, A. (1940). An agricultural testament [Online version]. Oxford, UK: Oxford University Press. Retrieved from the Small Farms Library: http://journeytoforever.org/farm library.html \#howard

Ikerd, J. (2015a). Can small farms be sustained economically? Journal of Agriculture, Food Systems, and Community Development, 5(3), 9-11. http://dx.doi.org/10.5304/jafscd.2015.053.001

Ikerd, J. (2015b). Toward a Food Ethic. Journal of Agriculture, Food Systems, and Community Development, 6(1), 3-5. http://dx.doi.org/10.5304/jafscd.2015.061.001

Ikerd, J., Gamble, L., \& Cox, T. (2015). Deep sustainability; The essentials. Retrieved from https://sites.google.com/site/sustainabilitydeep/

Rodale, J. I. (1948). The organic front [Online version]. Emmaus, Pennsylvania: Rodale Press. Retrieved from the Soil and Health Library website: https://soilandhealth.org/copyrighted-book/theorganic-front/

Steiner, R. (Author), \& Gardner, M. (Ed.). (1924/1993). Spiritual foundations for the renewal of agriculture: $A$ course of lectures held at Koberwitz, Silesia, June 7 to 16, 1924. C. E. Creeger \& M. Gardner (Trans.). Kimberton, Pennsylvania: Bio-Dynamic Farming and Gardening Association. 